\title{
ANTITUMOR ACTIVITY:! VIA INHIBITION OF GLYCOSPHINGOLIPID BIOSYNTHESIS
}

\author{
JIN-ICHI INOKUCHI*, INEZ MASON and NORMAN S. RADIN \\ Mental Health Research Institute, University of Michigan. Ann Arbor. MI 48109 (U.S.A.) \\ (Received 8 July 1987) \\ (Revised version received 1 September 1987) \\ (Accepted 3 September 1987)
}

\section{SUMMARY}

The production by cancer cells of glycolipids, perhaps derived partly from host glycolipids, may play essential roles in malignancy, tumor growth, immunity from host immunodefense, and metastasis. The glycolipids are derived from the primary glycolipid, glucosylceramide (GlcCer), which is formed enzymatically from ceramide and uridine diphosphoglucose (UDP-glu). Injection of an inhibitor of this enzyme into mice bearing intraperitoneal Ehrlich ascites tumor cells (EATC) resulted in complete cure of about $30 \%$ of the mice and marked prolongation of life in the remainder. Almost all of the surviving mice were immune to a second inoculation of EATC. Injection of GlcCer stimulated cancer cell growth about $50 \%$ but this was largely reversed by the inhibitor. This type of inhibitor may have wide application to cancer chemotherapy.

\section{INTRODUCTION}

The gly cosphingolipids of cancer cells may play essential roles in malignancy [1,2], tumor growth [3], immunity from host immunodefense [4], and metastasis [5]. Novel glycolipids have been isolated from cancerous cells [6-8] and some human tumors (melanomas) have been killed by the injection of antibodies made to react with a specific glycolipid, ganglioside GD3 $[9,10]$. These glycolipids are made by glycosylation of the primary glycolipid, GlcCer, which is formed enzymatically from ceramide and UDP-glu. Patients with Gaucher disease, a genetic disorder marked by deficient GleCer glucosidase activity and accumulation of GleCer, seem to have an unexpectedly high incidence of

* Present address: Faculty of Pharmaceutical Sciences, Fukuoka University, Nanakuma 8-19-1. Jonan-ku, Fukuoka 814-01, Japan.

Address correspondence to Dr. N. Radin. 
leukemia and other disorders of B-cell proliferation $[11,12]$. The suggestion has been offered that the high content of tissue GlcCer somehow overstimulates Bcell proliferation with consequent malignant or benign transformation.

Gaucher patients not only accumulate large amounts of the lipid, but also suffer from severe hypertrophy of the spleen and liver. We have found [13] that injecting young mice with emulsified GleCer causes liver uptake of the GlcCer and rapid growth of the liver, up to $37 \%$ in 1 day. The growth is accompanied by increased formation of DNA, lipid, and protein. The effect is stronger when conduritol B epoxide, which blocks the catabolism of GleCer, is included with the glycolipid.

On the basis of the many reports of this sort, one may hypothesize that tumors are more sensitive than hosts to interference with glyeolipid synthesis, transport, or metabolic functions. Recently we developed an optically active form (D-threo) of 1-phenyl-2-decanoylamino-3-morpholino-1-propanol (PDMP, Fig. 1), which inhibits UDP-glu:ceramide glucosyltransferase [14]. Injection of PDMP into mice bearing intraperitoneal EATC, as described in the present paper, resulted in substantial cure. By contrast, injected GleCer stimulated EATC growth about $50 \%$ but the cells' growth was largely reversed by the inhibitor. This type of inhibitor may have wide application to cancer chemotherapy.

\section{MATERIALS AND METHODS}

Animals and treatment. Male mice of the ICR (Swiss Hsd) strain from Harlan-Sprague Dawley (Indianapolis, IN), were injected i.p. with saline containing $2 \times 10^{8} \mathrm{EATC}$ on day 0 . Each cage contained 5 mice which had been weight matched for similar means $(25 \mathrm{~g})$ and similar standard deviations by a computer program [15]. Treatment began $24 \mathrm{~h}$ later with i.p. injections of saline or PDMP acetate salt, dissolved in $40^{\circ} \mathrm{C}$ saline and injected at $10 \mu \mathrm{l} / \mathrm{g}$ body wt. Ten animals were assigned to each control or experimental group and fed

Stearoyl sphingosine: $\quad 3 \quad 2 \quad 1$

$$
\mathrm{CH}_{3}-\left(\mathrm{CH}_{2}\right)_{2}-\mathrm{CH}=\mathrm{CH}-\mathrm{CH}(\mathrm{OH})-\mathrm{CH}(\mathrm{NH}-\mathrm{s} \text { tearoy } \mathrm{l})-\mathrm{CH}_{2} \mathrm{OH}
$$

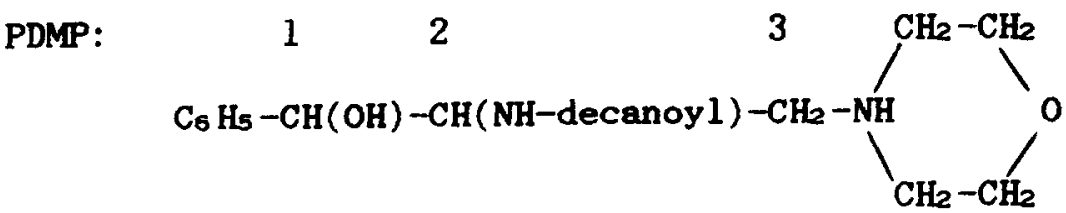

Fig. 1. Schematic structures of ceramide (the stearoyl isomer) and of PDMP. Because of the different numbering systems, carbon-1 of the inhibitor is equivalent to carbon- 3 of the natural lipid. 
standard laboratory chow. In almost all cases the mice were injected daily for a total of 10 doses.

UDP-glu:ceramide glucosyltransferase assay. Microsomes as source of enzyme were prepared by highspeed centrifugation and stored at $-70^{\circ} \mathrm{C}$ before use. The incubations were at $37^{\circ} \mathrm{C}$ for $30 \mathrm{~min}$ with microsomes, ATP, liposomal octanoyl sphingosine, UDP-[3 $\mathrm{H}] \mathrm{glu}, \mathrm{Mg}^{2+}$, and dithioerythritol [16].

Cerebroside emulsions. Injectable suspensions of $\mathrm{GlcCer}$ and galactosylceramide (GalCer) were prepared by mechanical grinding in saline $(10 \mathrm{mg} / \mathrm{ml})$ and injected at a dosage of $100 \mathrm{mg} / \mathrm{kg}$.

Statistics. The 1-tailed Student's $t$-test for unpaired samples was used.

\section{RESULTS}

The saline injected controls consistently showed rapid formation of EATC and ascites fluid, with markedly distended abdomens (median survival 24 days). About 30\% of the mice treated with PDMP were apparently. completely cured (Table 1). They showed no signs of ascites fluid formation at any time and at all times (>10 months now for the first group) looked healthy although weight gain was temporarily slow or negative. The remaining mice died from a solid tumor version of the cells, but somewhat later than the untreated mice. The median $\mathrm{T} /$ $\mathrm{C}$ ratios for the drug were $191 \%, 238 \%, 319 \%$ and $150 \%$ for the 4 experiments shown, well above the accepted minimal values for a 'highly promising' antineoplastic agent.

A dose response test with 10 daily injections of PDMP (not listed) showed that the $\mathrm{T} / \mathrm{C}$ index increased with increasing dosage, as did the percentage of total cure. All animals injected with 25 or $50 \mathrm{mg} / \mathrm{kg}$ died at about the same time

TABLE 1

\section{ANTITUMOR ACTIVITY OF PDMP (ACETATE SALT) IN MICE}

Column a indicates the low drug toxicity. Column $b$, which shows the change in mean body weight at the end of 10 days, indicates the drug toxicity as evidenced by subnormal weight gain. Normal, uninoculated mice gain about $4.5 \mathrm{~g}$ during this period. The weight gain by control mice is largely due to growth of EATC. Columns $c$ show the number of cured mice in parentheses; the other numbers include cured mice + mice bearing a solid tumor.

\begin{tabular}{|c|c|c|c|c|}
\hline $\begin{array}{l}\text { Dosage } \\
\text { (mg/kg per day) }\end{array}$ & $\begin{array}{l}\text { Surviving } \\
\text { at } 10 \text { days } \\
\text { (a) }\end{array}$ & $\begin{array}{l}\text { Body wt. } \\
\text { change } \\
\text { (b) }\end{array}$ & $\begin{array}{l}\text { Surviving } \\
\text { at } 60 \text { days } \\
\text { (c) }\end{array}$ & $\begin{array}{l}\text { Surviving } \\
\text { at } 90 \text { days } \\
\text { (c) }\end{array}$ \\
\hline Saline controls & $10 / 10$ & $+10.9 \mathrm{~g}$ & $\mathbf{0}$ & 0 \\
\hline $1 \times 100$, days $1-10$ & $10 / 10$ & +1.62 & $7(4)$ & $4^{\cdot}(4)$ \\
\hline $2 \times 100$, days $1-5$ & $10 / 10$ & +3.78 & $5(3)$ & $3^{a}(3)$ \\
\hline $\begin{array}{l}1 \times 150, \text { days } 1-10 \\
2 \times 150 \text {, days } 1-5 \text {, }\end{array}$ & $10 / 10$ & -0.36 & $7(3)$ & $5(3)$ \\
\hline $1 \times 150$, days $6-10$ & $8 / 9$ & -3.49 & $5(3)$ & $5(3)$ \\
\hline
\end{tabular}

- The mice with solid tumors were killed before 90 days to reduce suffering. 
TABLE 2

TOXICITY TEST WITH PDMP INJECTED 10 TIMES AT 100 mg/kg per DAY

The data represent means and standard deviations. The initial mean body weights were $24.4 \mathrm{~g}$.

\begin{tabular}{lll}
\hline & Controls & PDMP \\
\hline Body wt. (g) & $28.8 \pm 1.4$ & $26.5 \pm 1.2^{* *}$ \\
Liver wt. (g) & $1.61 \pm 0.11$ & $1.32 \pm 0.12^{* *}$ \\
Liver wt. (\% of body) & $5.57 \pm 0.24$ & $4.97 \pm 0.52^{* *}$ \\
Kidney wt. (g) & $0.394 \pm 0.045$ & $0.329 \pm 0.027^{* *}$ \\
Kidney wt. (\% of body) & $1.37 \pm 0.11$ & $1.24 \pm 0.13^{*}$ \\
Brain wt. (g) & $0.465 \pm 0.025$ & $0.444 \pm 0.015^{*}$ \\
Brain wt. (\% of body) & $1.61 \pm 0.08$ & $1.67 \pm 0.08$ \\
Spleen weight (g) & $0.099 \pm 0.018$ & $0.095 \pm 0.019$ \\
Spleen wt. (\% of body) & $0.34 \pm 0.05$ & $0.36 \pm 0.07$ \\
\hline
\end{tabular}

$* P<0.025, * * P<0.05$.

as the controls, although the drug reduced the chance of early death. The percentages surviving for 60 days were $10 \%, 20 \%$ and $50 \%$ for 75,100 and 125 $\mathrm{mg} / \mathrm{kg}$ respectively.

As a test of toxicity we injected 10 normal, non-cancerous mice with PDMP daily for 10 days, then killed them $5 \mathrm{~h}$ later (Table 2). The 10 control mice gained an average of $4.5 \mathrm{~g}$ while the treated mice gained $2.1 \mathrm{~g}$. The treated mice had distinctly smaller weights: $8 \%$ in bodies, $18 \%$ in livers, and $17 \%$ in kidneys. The spleens were slightly but not significantly smaller and the brains were $4.6 \%$ smaller $(P<0.025)$. Using the data for percent of body weight, to minimize the importance of general toxicity, we found that only the livers and kidneys were significantly smaller $(P<0.05)$. The above decreases in organ size were in the direction expected from a diminished level of tissue GlcCer, since injection of the latter produced liver growth [13].

In order to observe less evanescent responses in a similar test, we killed the animals $40 \mathrm{~h}$ after the last injection following 12 daily injections. Here, of the absolute weights, only the kidneys were statistically different in treated mice, $11 \%$ smaller $(P<0.05)$. Comparing the 40 -h and 5 -h experiments it seems likely that the liver weights renormalized faster than the kidneys, perhaps a reflection of faster glycolipid turnover.

Cell counts made on orbital blood showed no abnormalities in RBC, WBC, differential monocytes, lymphocytes, eosinophiles, and neutrophils. This failure to harm the bone marrow and related systems compares favorably with the high toxicity of many antineoplastics.

Evidence that GlcCer metabolism is a rate-limiting factor in EATC growth was obtained by injecting a suspension of GlcCer into one group of 10 mice inoculated 1 day earlier with EATC as before. In one experiment, the mice were killed 1 day after the last of 8 daily injections and the ascites cells were flushed out of the abdomen with buffered saline and washed. The salineinjected controls yielded $3.07 \mathrm{ml}$ of packed, centrifuged cells (mean value per 
mouse), while the GlcCer-injected mice yielded $4.68 \mathrm{ml}$, an increase of $52 \%(P<$ 0.05). Cell counts with a hemacytometer showed a similar increase so it can be concluded that the cells increased in number rather than in size. Mice treated with PDMP and GlcCer yielded $1.57 \mathrm{ml}$ of cells (a $66 \%$ decrease compared with the GlcCer cells). This statistically significant difference demonstrates the ability of PDMP to inhibit EATC growth even in the presence of GlcCer. It seems as though the rate of exogenous GleCer uptake and utilization was not rapid enough to supply all the requirements of the EATC for this lipid.

A similar experiment gave very similar results (Table 3). Here the treatments were begun 3 days after EATC inoculation, only 5 injections were given, and the mice were killed 1 day later. GalCer, a glycolipid similar to GlcCer, showed no stimulation of EATC growth. The two lipids are catabolized to ceramide, sphingosine, and fatty acid, but only the glucolipid is anabolized to gangliosides. It is important to note that the EATC absorbed both glycolipids, as shown by thin-layer chromatography. Normal mice injected with GlcCer did not show the formation of a significant number of free peritoneal cells.

Further evidence that PDMP acts via its inhibition of GlcCer biosynthesis came from assay of glucosyltransferase. Microsomes from EATC $(0.50 \mathrm{mg}$ protein) required $20 \mu \mathrm{M}$ PDMP to reduce the glucosyltransferase activity in half. The microsomes from normal liver (72 $\mu \mathrm{g}$ protein) required $5 \mu \mathrm{M}$ PDMP. While the EATC enzyme seems to be less sensitive to the inhibitor, the intraperitoneal concentration of inhibitor is initially very high. The Lenantiomer of PDMP did not inhibit the EATC enzyme, as observed for normal mouse tissue [14].

Unexpectedly we found that glucosyltransferase specific activity in the microsomal fraction of the EATC $(0.41 \mathrm{nmol} / \mathrm{h}$ per $\mathrm{mg}$ protein) was only $1 / 7$ that of liver microsomes from normal ICR Swiss mice. Our tentative conclusion from this is that these cells obtain much of their GlcCer from the peritoneum. Thus the effectiveness of the drug can tentatively be ascribed to a blockage of GleCer synthesis by the host's cells.

Tumors appear to secrete ('shed') glycolipids which protect them from the host's immunosurveillance system, rendering them resistant to immunological

TABLE 3

GROWTH OF EHRLICH ASCITES CELLS IN VIVO IN THE PRESENCE OF CEREBROSIDES AND GLUCOSYLTRANSFERASE INHIBITOR

\begin{tabular}{lcc}
\hline Treatment & $\begin{array}{l}\text { Vol. of packed cells } \\
\text { (ml/mouse) }\end{array}$ & \% of control \\
\hline Saline controls & $2.72 \pm 0.95$ & 100 \\
GlcCer $(100 \mathrm{mg} / \mathrm{kg})$ & $4.13 \pm 0.63$ & $152^{* *}$ \\
GalCer $(100 \mathrm{mg} / \mathrm{kg})$ & $2.29 \pm 1.21$ & 84 \\
GlcCer + PDMP $(100 \mathrm{mg} / \mathrm{kg})$ & $1.40 \pm 1.19$ & $51^{*}$ \\
PDMP & $1.68 \pm 0.86$ & $62^{*}$
\end{tabular}

${ }^{*} P<0.05$ compared with controls. ${ }^{* *} P<0.01$ compared with controls. 
defense [4,17]. If PDMP acts to reduce the EATC's resistance to the host's immunodefense system, one ought to find antibodies to EATC in treated mice. As a preliminary test of this hypothesis, we challenged 4 mice who had survived 63 days post-inoculation with another $2 \times 10^{6}$ EATC. These mice showed no effects of the reinoculation for $>8$ months more. Five other survivors were challenged 135 and 100 days after inoculation and four of them developed no EATC for $>5$ months of observation. Mice of this age, like the younger ones, are readily attacked by EATC. We conclude that the mice have been, in effect, 'live-cell vaccinated' with EATC plus PDMP.

Preliminary trials have been made in EATC mice with racemic mixtures of homologs of PDMP in which the decanoyl moiety was replaced with other unsubstituted saturated fatty acids. The hexanoyl and octanoyl homologs seemed to be inactive, while the longer chain homologs were able to protect the mice. Palmitoyl and stearoyl derivatives were somewhat more toxic; nevertheless the latter produced about $75 \%$ complete (asymptomatic) cure, as evaluated 96 days after inoculation.

\section{DISCUSSION}

A proliferation effect of a glycolipid, ganglioside GQ1b, was observed in cultured neuroblastomas [3], consistent with our findings with GlcCer in mice [13] and EATC. A similar effect was seen in vivo with a ganglioside mixture and human and rat tumors which were transplanted into nude mice [18]. Since these lipids are enzymatically converted to GlcCer and the many other glycolipids, it is not yet clear which compound is responsible for the growth effects. Possibly it varies with the cell type.

Data point to the need by some cancer cells to obtain much of their fatty acid [19], cholesterol [20], and L-asparagine from the host [21]. Tumors apparently secrete lipotrophic factors which stimulate the host to mobilize its stored fat, presumably for use by the tumor $[22,23]$. Glial cells of brain apparently cannot make GlcCer by synthesis and must obtain the lipid or a more-glycosylated glycolipid from adjacent sources [24]. A carrier protein which can transfer GleCer and other glycolipids from cell to cell has been characterized [25,26]. Glycolipids are also transferred through the blood stream in combination with lipoproteins [27]. These observations support our suggestion that EATC obtains much of its GlcCer from the host. It is possible that tumor cells, as they die from lack of glycolipid due to PDMP treatment, transfer their remaining glycolipids to still-intact tumor cells. This possible complication could explain the growth stimulating action of dying or dead cancer cells on potent cancer cells [28].

The evidence mentioned above points to the need for urgent development of more and better inhibitors of glycolipid synthesis, membrane binding and transport. Hakomori, in a recent review of some relationships between glycolipids and cancer [1], pointed out that "The composition of ... membranes changes dramatically with ... the onset of cancer. Exploiting such changes 
could lead to improved diagnosis and treatment of cancer.' The use of inhibitors of glycolipid synthesis would seem to be one important method of exploitation. Our laboratory continues to develop variants on the PDMP structure and to test them with the other kinds of cancer that might be more predictive of efficacy in human use.

Supported by grants from NIH (HD07406) and from The University of Michigan Cancer Center and Cancer Research Institute. NSR has a Jacob Javits Investigatorship from NIH.

\section{REFERENCES}

1 Hakomori, S. (1986) Glycosphingolipids. Sci. Am., 254, 44-53.

2 Thurin, J., Thurin, M., Herlyn, M., Elder, D.E., Steplewski, Z., Clark Jr., W.H. and Koprowski, H. (1986) GD2 ganglioside biosynthesis is a distinct biochemical event in human melanoma tumor progression. FEBS Lett., 208, 17-22.

3 Tsuji, S., Arita, M. and Nagai, Y. (1983) GQ1b, a bioactive ganglioside that exhibits novel growth factor-like activities in the two neuroblastoma cell lines. J. Biochem., 94, 303-306.

4 Ladisch, S., Gillard, B., Wong, C. and Uish, L. (1989) Shedding and immunoregulatory activity of YAC-1 lymphoma cell gangliosides. Cancer Res., 43, 3808-3813.

5 Laferté, S., Fukuda, M.N., Fukuda, M., Dell, A. and Dennis, J.W. (1987) Glycosphingolipids of lectin-resistant mutants of the highly metastatic mouse tumor cell line, MDAY-D2. Cancer Res., 47, 150-159.

6 Taki, T., Hirabashi, Y., Ishikawa, H., Ando, S., Kon, K., Tanaka, Y. and Matsumoto, M. (1986) A ganglioside of rat ascites hepatoma AH 7974F cells. J. Biol. Chem., 261, 3075-3078.

7 Fukuda, M.N., Bothner, B., Lloyd, K.O., Rettig, W.J., Tiller, P.R. and Dell, A. (1986) Structures of glycosphingolipids isolated from human embryonal carcinoma cells. J. Biol. Chem., 261, 5145 $-5153$.

8 Hanqing, H., Avrova, N., Mansson, J., Molin, K. and Svennerholm, L. (1986) Gangliosides and neutral glycosphingolipids of normal tissue and oat cell carcinoma of human lung. Biochim. Biophys. Acta, 878, 360-370.

9 Hellström, I., Brankovan, V. and Hellström, K.E. (1985) Strong antitumor activities of IgG3 antibodies to a human melanoma-associated ganglioside. Proc. Natl. Acad. Sci. U.S.A., 82, 1499 -1502 .

10 Houghton, A.N., Minzter, D., Cordon-Cardo, C., Welt, S., Fliegel, B., Vadhan, S., Carswell, E., Melamed, M.R., Oettgen, H.F. and Old, L.J. (1985) Mouse monoclonal IgG3 antibody detecting GD3 ganglioside: a phase I trial in patients with malignant melanoma. Proc. Natl. Acad. Sci. U.S.A., 82, 1242-1246.

11 Fox, H., McCarthy, P., André-Schwartz, J., Shoenfeld, Y. and Miller, K.B. (1984) Gaucher's disease and chronic lymphocytic leukemia. Possible pathogenetic link between Gaucher's disease and B-cell proliferations? Cancer, 54, 312-314.

12 Burstein, Y., Rechavi, G., Rausen, A.R., Frisch, B. and Spirer, Z. (1985) Association of Gaucher's disease and lymphoid malignancy in 2 children. Scand. J. Haematol., 35, 445- 447.

13 Datta, S.C. and Radin, N.S. (1986) Glucosylceramide and the level of the glucosidasestimulating proteins. Lipids, 21, 702-709.

14 Inokuchi, J., and Radin, N.S. (1987) Preparation of the active isomer of 1-phenyl-2decanoylamino-3-morpholino-1-propanol, inhibitor of murine glucocerebroside synthetase. $J$. Lipid Res., 28, 565-571.

15 Radin, N.S. and Klinger, P. (1986) A computer program for selecting animals for control and experimental groups in biochemical studies. Comput. Appl. Biosci. 2, 107-109.

16 Vunnam, R.R. and Radin, N.S. (1980) Analogs of ceramide that inhibit glucocerebroside synthetase in mouse brain. Chem. Phys. Lipids, 26, 265-278. 
17 Young Jr., W.W., Borgman, C.A. and Wolock, D.M. (1986) Modes of shedding of glycosphingolipids from mouse lymphoma cells. J. Biol. Chem., 261, 2279-2283.

18 Alessandri, G., Fillipeschi, S., Sinibaldi, P., Cappa, P.-M. and Gullino, P.M. (1987) Ganglioside enhanced growth of transplanted tumors and metastasis. Proc. Am. Assoc. Cancer Res., 28, 56.

19 Sauer, L.A. and Dauchy, R.T. (1987) Blood nutrient concentrations and tumor growth in vivo in rats: relationships during the onset of an acute fast. Cancer Res., 47, 1065-1068.

20 Brennemann, D.E., McGee, R. and Spector, A.A. (1974) Cholesterol metabolism in the Ehrlich ascites tumor. Cancer Res., 34, $2605-2611$.

21 Broome, J.D. (1963) Evidence that the L-asparaginase of guinea pig serum is responsible for its antilymphoma effects. J. Exp. Med., 118, 121-148.

22 Kitada, S., Hays, E.F., Mead, J.F. and Zabin, I. (1982) Lipolysis induction in adipocytes by a protein from tumor cells. J. Cell. Biochem., 20, 409-416.

23 Masuno, H., Yamasaki, N. and Okuda, H. (1981) Purification and characterization of a lipolytic factor (toxohormone-L) from cell-free fluid of ascites sarcoma 180. Cancer Res., 41, 284-288.

24 Radin, N.S., Brenkert, A., Arora, R.C., Sellinger, O.Z. and Flangas, A.L. (1972) Glial and neuronal localization of cerebroside-metabolizing enzymes. Brain Res., 39, $163-169$.

25 Metz, R.J. and Radin, N.S. (1982) Purification and properties of a cerebroside transfer protein. J. Biol. Chem. 257, 12901-12907.

26 Yamada, K., Abe, A. and Sasaki, T. (1985) Specificity of the glycolipid transfer protein from pig brain. J. Biol. Chem., 260, 4615-4612.

27 Loeb, J.A. and Dawson, G. (1982) Reversible exchange of glycosphingolipids between human high and low density lipoproteins. J. Biol. Chem., 257, 11982-11987.

28 Dykes, D.J., Griswold, Jr., D.P. and Schabel, Jr., F.M. (1976) Growth support of small melanoma implants with nitrosourea-sterilized fractions of the same tumor. Cancer Res., 36, 2031-2034. 